\title{
Naval museum spaces a study on accessibility and visibility based on the relationship between the sea and land
}

\author{
Nurcan Gül* \\ Sevilay Erk** (D)
}

\begin{abstract}
The relationship between location and context, design, and usage gains importance in architectural structures. The interrelated patterns of different syntactic and semantic layers compose the built space especially museums or exhibition spaces. The museum spaces have a considerable part of everyday life in terms of social interaction. The accessibility, visibility, and circularity of the museum spaces are affecting the integration of the human-space activity. The museums by the sea are recognized with the silhouette of the city. These museums are accessible from the seaway and overland routes. It is important that the museums as an exhibition space in the city are visible from both the sea and the land and provide two different accesses. For this reason, the study investigates two naval museums which emphasize the importance of location belonging and the type of the museum. Within the scope of the study, Genova Galata Museo Del Mare in Italy and the Istanbul Deniz Müzesi in Turkey with a similar location and function are examined. The museums are close to the seaway and visible from the sea. However, Istanbul Deniz Müzesi's access is provided from the motorway due to the actual usage. On the other hand, in the case of Galata, the situation is the opposite. Thus, the museum structure is passed through in it and creates the connection space between the sea and land. The aim of the study is not only a representation of the maritime structure of the museum in a city that is the sea but also to highlight the importance of access from both sides. Furthermore, with the examination of the visibility, accessibility and circularity affect, the usage and timerelated changes in the museum to be focused. For this purpose, use from the sea and the land, the relationship between the land and the sea will be evaluated as a bridge of the ground floor. In this study, the space syntax analysis method is applied. Space syntax provides an analytical analysis of human-environment relations, accessibility, and movement values. (Hillier et al., 1987). The relevant results will create a research base for further use and change over time. In conclusion, in two different sea countries' naval museums are evaluated with the context of location and usage comparatively. The accesses of the museums and exhibitions areas are also evaluated by the visibility, accessibility, circularity analyses. A scientific base has been created to examine past, present, and future usage.
\end{abstract}




\section{Introduction}

\subsection{Galata Museo del Mare-Italy}

The Galata Museo del Mare was designed by Spanish architect Guillermo Vázquez Consuegra and opened in 2004. The project was selected with an international idea contest which was built within the scope of architectural renovation and the historical protection of the Genovese shipyard. The museum uses the ruins of the shipyard. The museum is located on the grounds of the Porto Antico, in the Palazzo Galata, in the Darsena district. The museum consists of four floors with exhibition areas. Having the $10000 \mathrm{~m} 2$ area makes the museum the largest one in the Mediterranean. Maritime Museums Design Office of the city of Genoa organizes the installation of the exhibitions. The museum's light glass structure, aluminum joinery create the new frame of the vaulted structure. This allows creating a gap between the new façade and the historical façade. The museum building gives the opportunity to historical shipyard façade seen completely from outside (Figure 1). Therefore, the museum reflects the maritime history of the city of Genoa with all its aspects. The 100 years old building shows itself with its new structure. The building welcomes visitors with a large entrance hall on a scale sufficient for new public use and allows a view of the historical facade from the road (URL-1). The museum is placed at the center of the port of Genoa with its spatial organization.

On the ground floor, the entrance is provided from the seaside a large foyer meets the users. The foyer consists of the information desk, cafe, bookshop and offices where four historic boats, diver diorama is exhibited. The lighthouse guides the users to the exhibition areas with the narrow corridor and this narrow corridor links the four separated units. The first part is devoted to the auditorium and service area. The second part is located to the lighthouse axis that reveals the Fresco" by Renzo Piano and Genoa: the port after the middle ages. The third part exposes Andrea Doria and the Genoese galleys, the weapons of the republic. Finally, the fourth part is devoted to the large galley that Arsenal: the galley on the airport. After the galley part, the space formed between the historical building and the new façade displays Galeotti: Life on Board and includes the stairs which enable users to go up (Beydiz,2018).
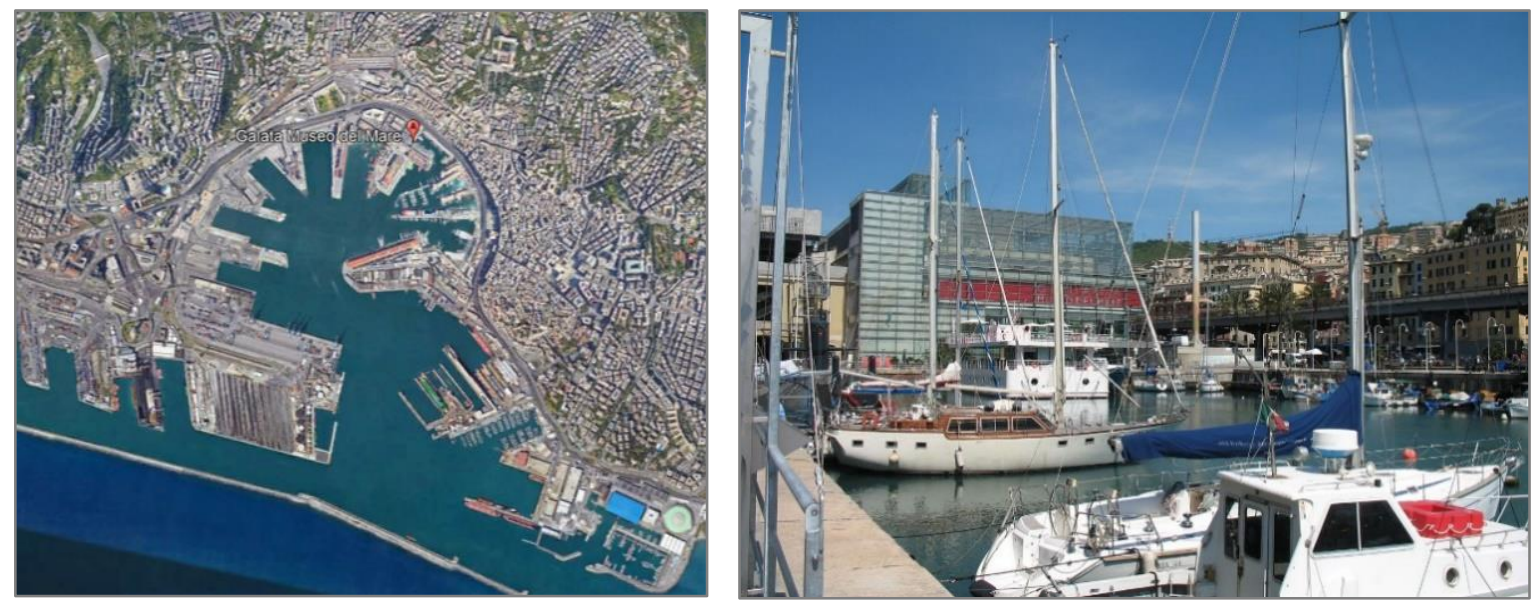

Figure 1 The location and the seaside facade Genova Galata Museo Del Mare, Italy. (URL-2)

\section{2. İstanbul Deniz Müzesi-Turkey}

The museum received the first prize in the Istanbul Deniz Müzesi national architecture competition opened in 2005. The museum was designed by Teğet Architecture as both the first example of a contemporary museum for the historical collection in Istanbul and the first public building built on the Bosphorus coast since the Bosphorus bridges. Located in the Beşiktaş district of İstanbul, the main exhibition building has three floors and sits on a $15.000 \mathrm{~m} 2$ area. The museum consists of 4 large halls and 17 rooms that are used as exhibition areas and the name of the directions of wind are given to the halls. In the museum, reign boats, navy clothes, manuscripts, 
ship models, banners, maps and portolan, paintings, tughras and crests, galleys, navigational instruments, ship head figures and weapons are exhibited. In the entrance section, there is an educational playground and a souvenir section for younger age groups. The museum was built adjacent to the historical structure (URL-3).

When the visitors enter the museum from the retreat zone on the Barbaros Street front, they find themselves in the boat gallery where is the main venue of the museum (Figure 2). On the ground floor, the historical most important galley welcomes the visitors in the large space with high ceilings and without columns. After that, the boats are proceeding chronologically by getting smaller in size. The tour ends with the boat used by Atatürk. At this point, users reach the mezzanine floor from the ground floor with a ramp. While the sultan boats on the 7 bridges are displayed, the boats on the ground floor are also given the opportunity to view from here. The bridges, whose lengths range from 25 meters to 55 meters, are carried by a 6-meter-high steel cage beam structure that creates a strong impact in the interior. The glass bridge encountered after walking upstairs takes the visitor to the historical building. When you go down the stairs of the historical building, visitors return to the entrance on the boulevard side (Gülhan,2014).
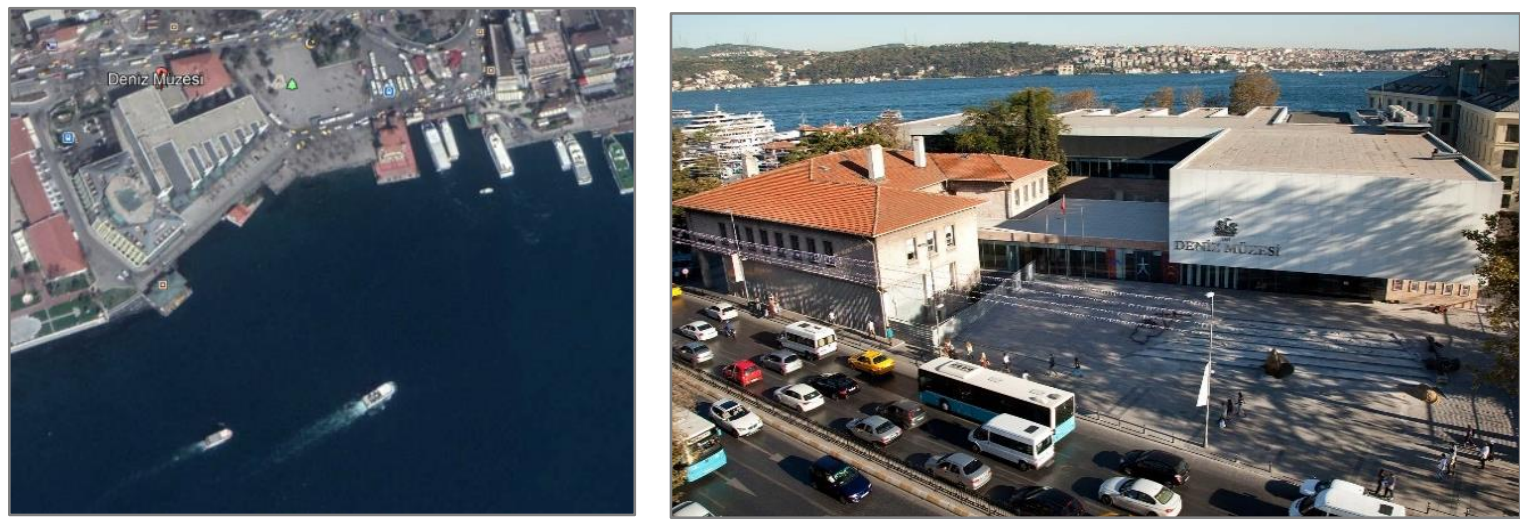

Figure 2 The location (URL-2) and entrance façade (URL-3) of İstanbul Deniz Müzesi, İstanbul

\section{The Conceptual Framework of The Study on Relation with Naval Museums}

\subsection{The Concept of the Space as a Social and Cultural Structure}

The space affects its users and can control their mood. A large part of the satisfaction is obtained from architecture arising from space. Architect models the space like a sculptor shaping the clay (Benedikt, 1979). According to Frank Llyod Wright, the reality of a building is not the physical frameworks that form it, it is the space that is created and lived by them (Benedikt, 1993). In Lefebvre's description, space is a product. The social space is also a product. The space is replaced by social relationships; it is not only supported by social relations but also produced by social relations (Lefebvre, 1991). The space contains varied meanings depending on the cultures, lifestyles, and changes in their social structures. Hillier and Hanson define human societies as spatial events. A society does more than exist in a place. It also takes a certain spatial form. Society organizes people first (Hillier at all, 1987).

Historically, architects and psychologists have great attention to nature with the perception of space. Coming up with the beginning of modern experimental psychology, space was first introduced as being of the principle in the practice of architecture (Van de Ven,1974). By that time, the concept of space has improved and reached different dimensions with different variations. Nevertheless, the most significant property of space is that it is organized for human actions for a particular goal. Therefore, it can be designed in a variety of forms and sizes depending on the function and technological data. The architect's experience copes with many issues in design. However, 'experience' is vague, particularly in design practicality worries. Unlike this situation, the 
theory of space syntax creates a new negotiation in concerns of architectural practicality (Ünlü and Edgü, 2007).

\subsection{The Theory of Space Syntax}

The space syntax is a method that focuses on the external features of buildings such as their connections, their positions, on the whole, their relations with all the spaces in the system, rather than their internal features such as shape, scale and texture in the numbering of the properties of the buildings. With the space syntax, the spaces are perceived as voids that square, street, cell and the area between the walls or other things that limit pedestrian movement or their visual field. According to the theory, there is a link between the forms and social forces. Therefore, space syntax contributes to the understanding of the interaction between social restrictions and design goals. The concept supposes that heaps of times, most people, will use the most basic path for their target. The path bears to contain the fewest alteration of way. When there is more variation of direction, there will be a more complicated system. Thus, network design becomes more insufficient (Hiller, 1984).

The theory was created by Bill Hillier, a professor at The Bartlett School of Architecture, University College London (UCL), who, willing to catch out on why social housing of the 1960s and $70 \mathrm{~s}$ in the United Kingdom was not processing; why a sense of community had not evolved. Therefore, he wanted to obtain the instruments of defining and analyzing how the housing layouts interacted with the space available. Then, he published a book with Julienne Hanson, called "The Social Logic of Space" (1984).
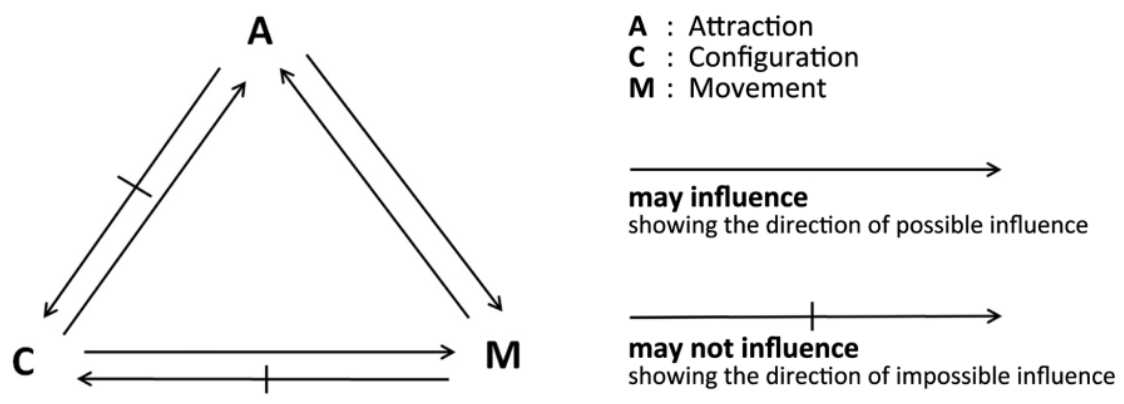

Figure 3 Attraction, configuration, and movement (Hillier, et. all., 1993).

Hillers' studies answer many questions of perception of city structures with various urban and spatial dimensions that influence the conception of pedestrian movements in the city. Furthermore, he figured out a vigorous relationship between the pedestrian and spatial integration of the built environment (Hiller and Hanson, 1984).

The built environment is generated by patterns that are interconnected with distinct syntactic and semantic layers, museums or exhibition spaces are a part of this crucial organization. Space syntax analysis is based on isovists (Benedikt, 1979; Hillier and Hanson, 1984); and provides analytical analysis of human-environment relations, accessibility, and movement values. Isovists and convex spaces for space syntax research are significant for the analysis (Hillier et al., 1987).

As Hillers points out in Figure 3, there is an asymmetrical relationship between attraction, configuration and movement. The configuration of the space has an impact on both visitors' behavior and their movement. The configuration may affect the location of the position of attractors; on the other hand, the position of attractors cannot affect the configuration. Similarly, the movement has no impact on the configuration. Only, movement and attractors are influencing each other (Hillier et al., 1993). 
Movement becomes a factor that creates relationships between the user and space, creates different spatial experiences. It enables the venue to communicate more with the user. Therefore, in this research, movement and perception topics must be clutched to figure out the morphology of museum layouts with their syntactic and semantic dimensions. According to Kuipers et al.'s (2003) work, visual perception and cognition have an important role in the movement, wayfinding and process of navigation by using the cognitive maps of the users' movement (Şalgamcıoğlu et. all., 2015).

The movement is a linear activity that people interact with others in space, see the environment from a point in it have a natural and require spatial geometry. The interaction needs a convex space where all points can see all others. From any point in space can be seen a changeable shape of the visual field which is isovist. The accumulation of these complex patterns enables users to perceive the built environment as a whole while moving (Figure 4). Hereby, each of these geometric ideas defines some perspective that uses or experiences the space. Accordingly, it can be said that they are vital aspects that provide organizing the buildings and their environment and grasp them. For instance, in the city, streets, avenues and alleys form the linear concept and the squares or public open spaces create the convex elements of the city. Their isovist features strongly affect the users in the spaces. Therefore, the pattern of the city created by these geometric aspects reflects human behaviors and experiences (Hillier, 2005).

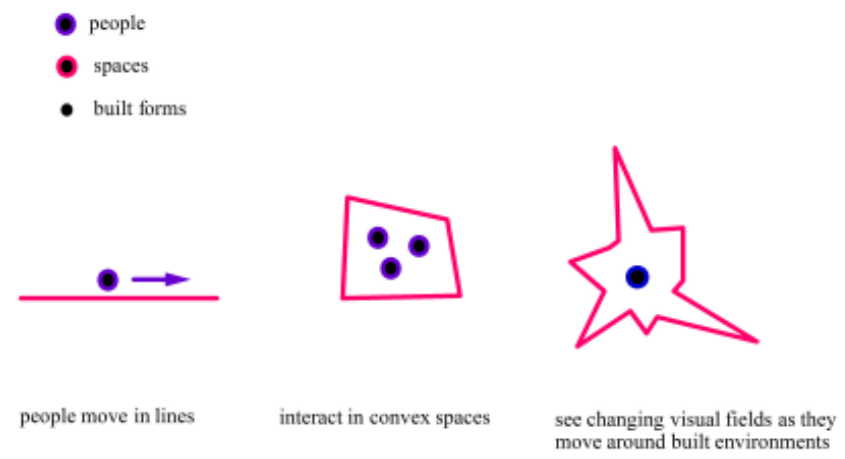

Figure 4 Space is not a background to the activity, but an intrinsic aspect of it (Hillier, 2005)

It can be said that these patterns are seen to be familiar for the visitor's discovery in museum spaces. While discovering the museum, start with following a skeleton of primary paths that connect to various perimeters of destinations and can be described in a syntactic term that more integrated paths of visibility and accessibility which are related to museum's spatial characteristics. These routes orient the local exhibition spaces where the movement is based on the local properties of exhibit accessibility and visibility (Wineman and Peponis, 2010).

By breaking down the subject and clarifying the basic terms used in Space Syntax it becomes easier to understand the different variables and its approach. The three basic conceptions in Space Syntax Analysis (Klarqvist,1993):

- Convex space, or convex polygon as some analyst calls it, is a polygon that no line drawn between any pair of points within that polygon goes outside of the polygon. In other words, no line crosses its perimeter.

- Axial space or an axial line is the longest line that chains convex polygons. It's a straight line linked to the notion of visibility and that can be followed by foot.

- Isovist space is the total area that can be viewed from a point, in three dimensions.

The measured spatial structure is demonstrated by using syntactic maps, with the same terminology: 
- Convex map depicts the least number of convex spaces that fully cover a layout and the connections between them. The interface map is a special kind of convex map showing the permeable relations between the outdoor convex spaces to the adjacent building entrances.

- Axial map depicts the least number of axial lines covering all convex spaces of a layout and their connections.

- Isovist map presents the areas that are visible from convex spaces or axial lines.

The four syntactic measures that can be calculated for using a quantitative representation of a building or urban layout:

- Connectivity measures the number of depths that are directly connected to a space. This is called a local measure.

- Integration is a static global measure. It indicates the degree to which a line is more integrated, or segregated, from a system as a whole.

- Mean Depth is the number of point depths is calculated for the average depth and the shortest path is determined for each grid. This measurement is useful in understanding human movement in building environments.

- Circularity is a measurement of compactness, which is the ratio of the square of the perimeter to the area. It is not only related to the space which is approximate to the circle but also related to the center of the viewpoint in the space. Therefore, circularity measurement gives the shape of space and centrality of the viewpoint within that space. It is a crucial parameter to discuss the geometry of the structure and spatial relation (Şalgamcığolu, 2013).

The accumulations of visible real surfaces in space generate the environment. Benedikt (1979) defines an isovist as the set of all points seen from a certain point in space and relating to an environment. When the position is changed, the shape and size of the visible field are changed respectively. The amount of evident size and shape properties requires numerical measurements. The accumulation of the scalar isovist field is composed of these measures. Thus, the environment can be defined with groups of isovists and isovist fields alternatively. This technique is appropriate for perceptual and behavioral studies in architecture, such as privacy, view control and spaciousness judgments. Hence, the isovists and isovist fields contribute to the significance of general architectural concepts about space. Furthermore, it is expected that the theory of knowledge-space can help provide efficient common ground for designers and researchers (Benedikt, 1979).

The profile of route vision is a technique for decisive how individual features of isovists alter through the route. Lynch (1965) tries to describe the visual experience through an annular route by fixing graphically the route and demonstrating it as a one-line with especially attractive views that are indicated by arrows (Dalton and Dalton, 2001). According to Hillier et. Al (1982) museum study suggested that reviewing the designs could create a fairly distinct pedagogic potential and social experience to a detailed layout. It can be said that permitting the variety of routes, stimulates a more investigative visiting style, and at the same time decrease the recognition of the other visitors, and guides to less organized and shorter encounters between them. Different schemes proposed different results in terms of the spatial culture; which could be more public, ceremonial or more experimental and specific (Hillier and Tzortzi, 2016).

\section{Methodology Regarding the Case Study and Analysis}

\subsection{Introduction of the Case Studies}

In this study, respecting the syntactic analysis, a comparative study is made at selected two naval museums. These two chosen naval museum structures are located on the seafront, which is the 
same as a similar function in place and context, added to the historic structure and built on the same years. The relationship of the museums with these sea cities is provided by the main entrance and emergency exit gates located on the land side and the seaside (Figure 5-6). The aim of the study is to evaluate its examinability by both sea and land. It demonstrates that these structures with seafront are used as a bridge that also provides land-sea transition and they can be used actively in both entrances.

In this investigation, quantitative methods that are involved in the space syntax methodology are used. Syntax 2D software that is developed by the University of Michigan is applied in this study. The software provides to examine relationships among the two naval museum compositions (Figure 8), Galata Museo del Mare and İstanbul Deniz Müzesi relying on their convex spaces (Figure 9), the shortest route between the entrance and vertical circulation.

Demonstrating the active usage of both the land and sea entrance of the naval museums located on the seashore to provide the land and sea relationship (Figure 7), increasing accessibility and reinforcing the connection are the key goals of this study. For this purpose, it was studied with visibility and accessibility analyzes used as data that led the discussion. Therefore, connectivity, circularity, mean depth, integration measures and isovist analyses were performed on the ground floor plans (Figure 8) of both museum structures. The visibility of the spaces was analyzed by conducting isovist analysis on a certain route between the main entrance, exhibition spaces, and the emergency exit.
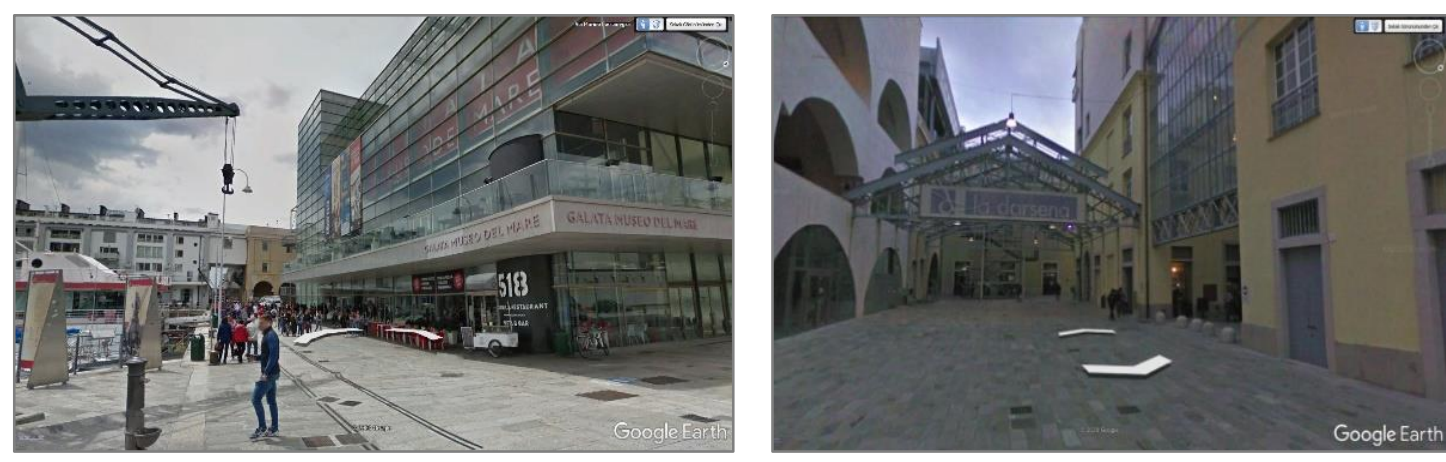

Figure 5 Galata Museo Del Mare Views from the seaside used as the main entrance and from the land used as an emergency exit (URL-3)
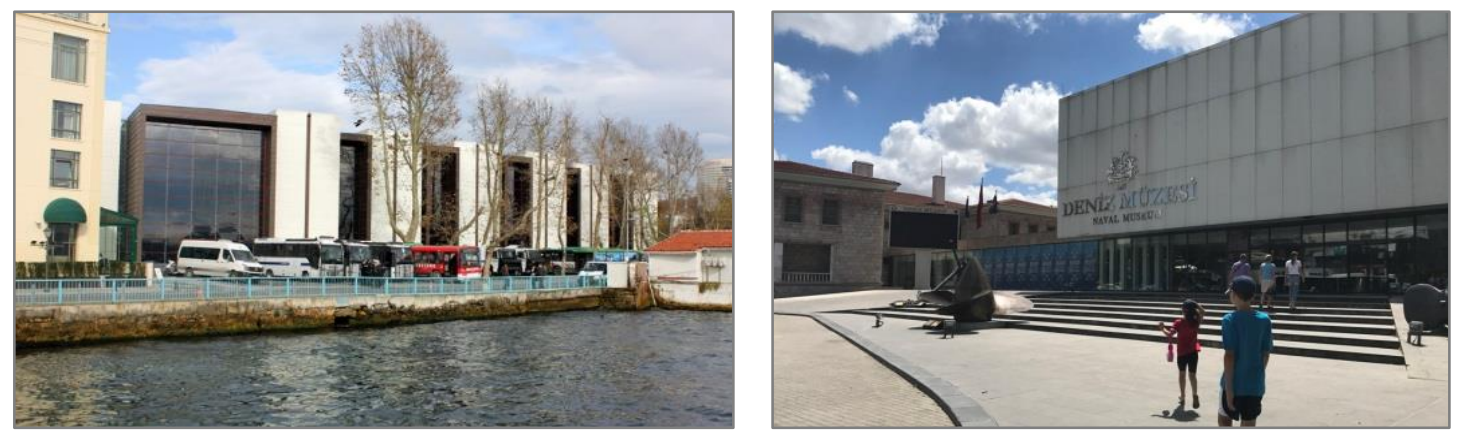

Figure 6 İstanbul Deniz Müzesi Views from the seaside used as an emergency exit and from the land used as the main entrance (URL-3) 


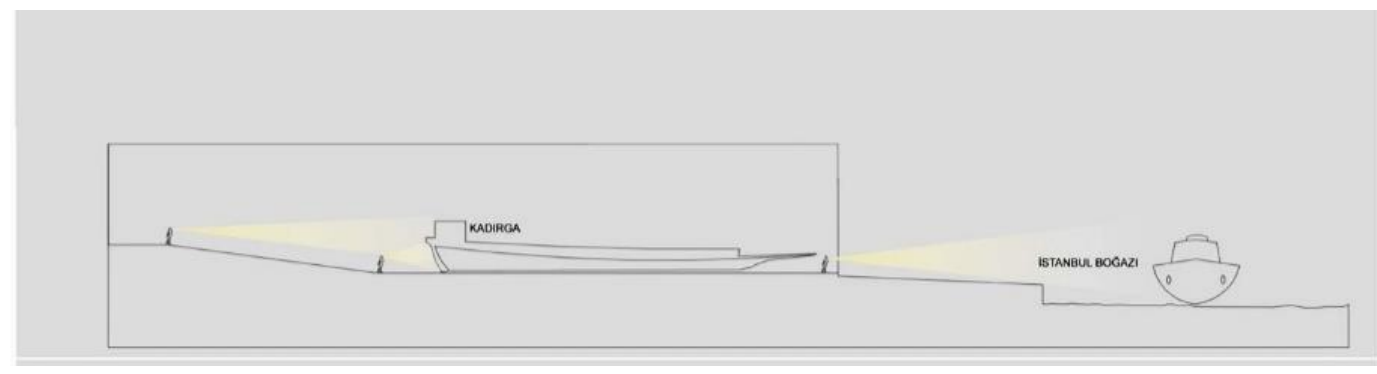

Figure 7 The section of the İstanbul Deniz Müzesi regarding the bridge between sea and land (URL-3)
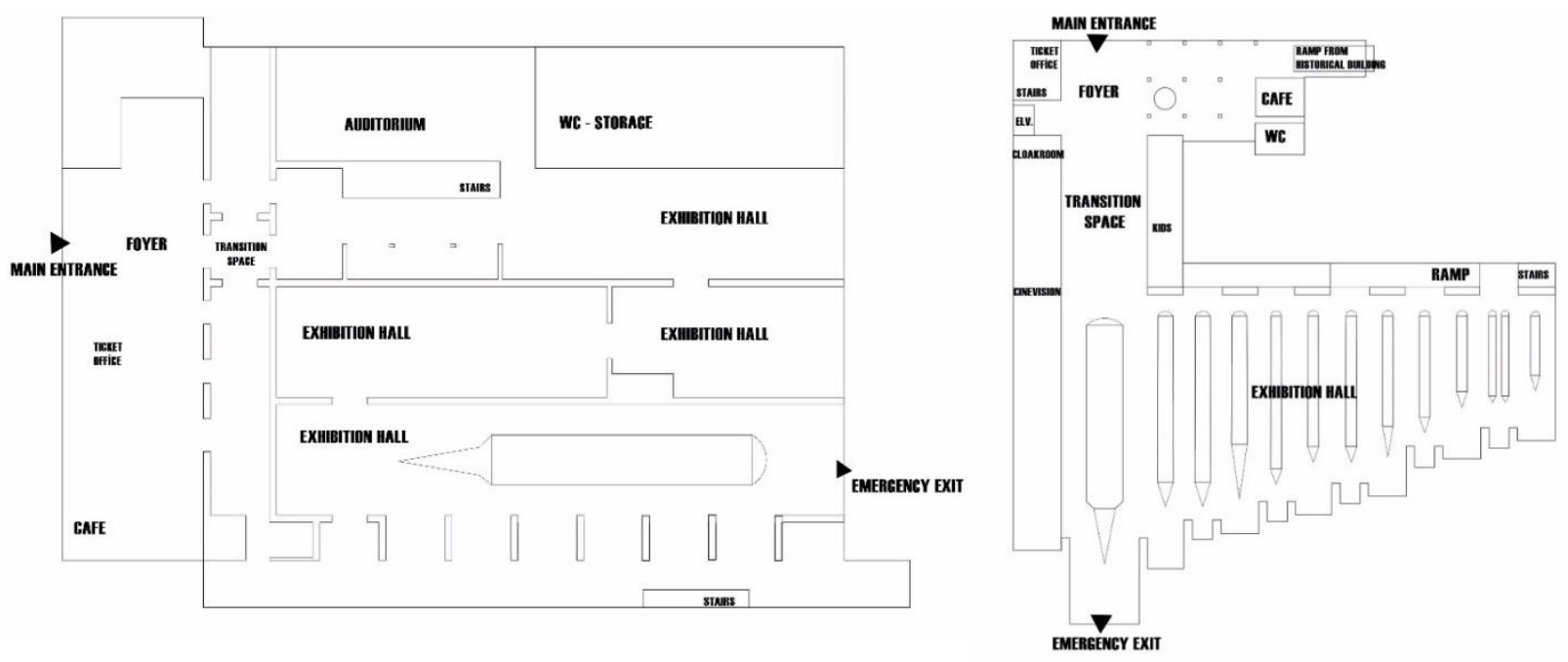

Figure 8 Ground floor plan of Genova Galata Museo Del Mare (left), Ground floor plan of İstanbul Deniz Müzesi (right)

\subsection{Analyses of the Case Studies}

In the study, two naval museums which are located at the seaside are selected. Both seaside and landside have interacted with the museum user actively. In order to represent the continuity of the urban-human relationship in the museum structure, the importance of the entrance from the urban areas and the circulation of the exhibited space; the circularity, connectivity and integration analyzes were applied to the ground floors (Figure 8). For understanding the human movement in the buildings through the exhibition space to the vertical circulation spaces, the mean depth analysis was used. To evaluate the visibility and accessibility of both two entrances and exhibition spaces, isovist analyses were performed regarding the nodes specified on the route.

The data obtained for every node of convex spaces are circularity, connectivity integration and mean depth (Figure 11). These four data subjects are the main concepts discussed in space syntax theory. In addition to that, these data were calculated one by one for every node (Table 1). Since homogenous colors are obtained, each node selected the center of the convex spaces. The isovist point maps (Table 2-3) were generated for each node that defines the route from the entrance to the vertical circulation point. Due to the size of galleys that obstacle the accessibility and visibility, the exhibited elements were identified as a wall to the software. The configurations of both museums are different. Galata Museo del Mare is composed of a sequence of spaces and the exhibition spaces separated by the walls. İstanbul Deniz Müzesi is an open plan, and the galleys direct the movement. 

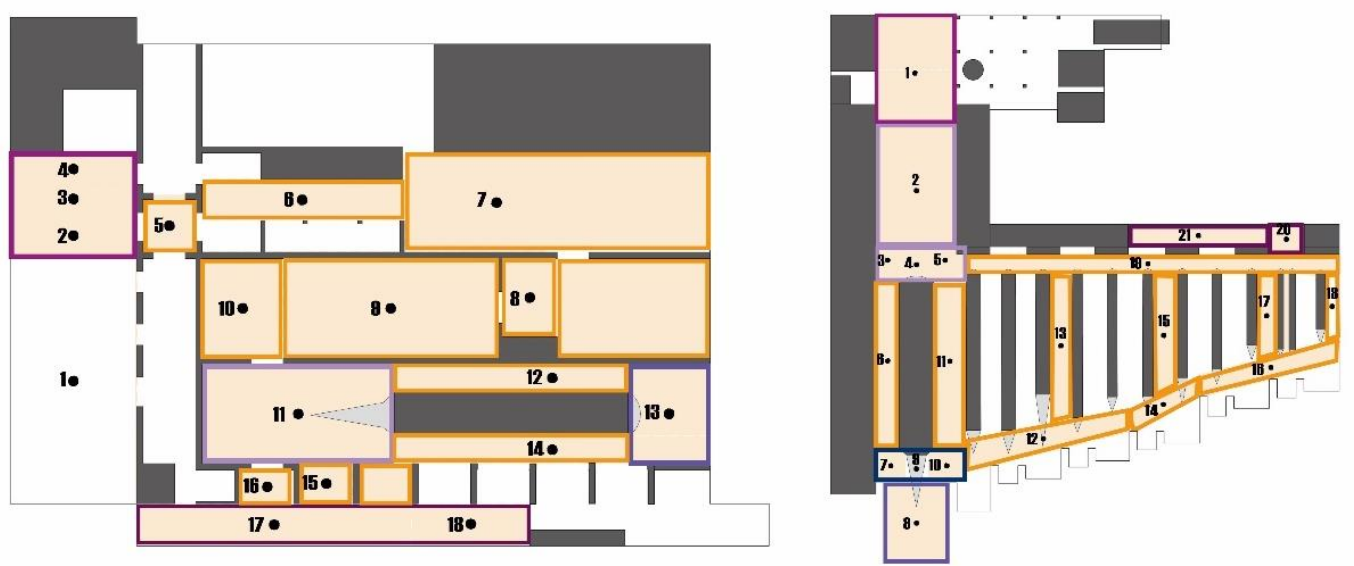

Page | 374

Figure 9 Genova Galata Museo Del Mare the path points of isovist analysis and convex spaces (left), İstanbul Deniz Müzesi the path points of isovist analys and convex spaces (right)

Both of the museum circulation paths have been drowned by two paths. One of them is the present route from the main entrance to the vertical circulation space (red line). The red line starts with the existing entrances hall, passes through the galleries, and ends with the upper circulation core. The second route is from the emergency exit to the vertical circulation space (green line) (Figure 10). The green line starts with the emergency exit, passes through the galleries, and ends with the upper circulation core. The main objective of the paths is the making shortest way to reach the second floor by seeing the main gallery.
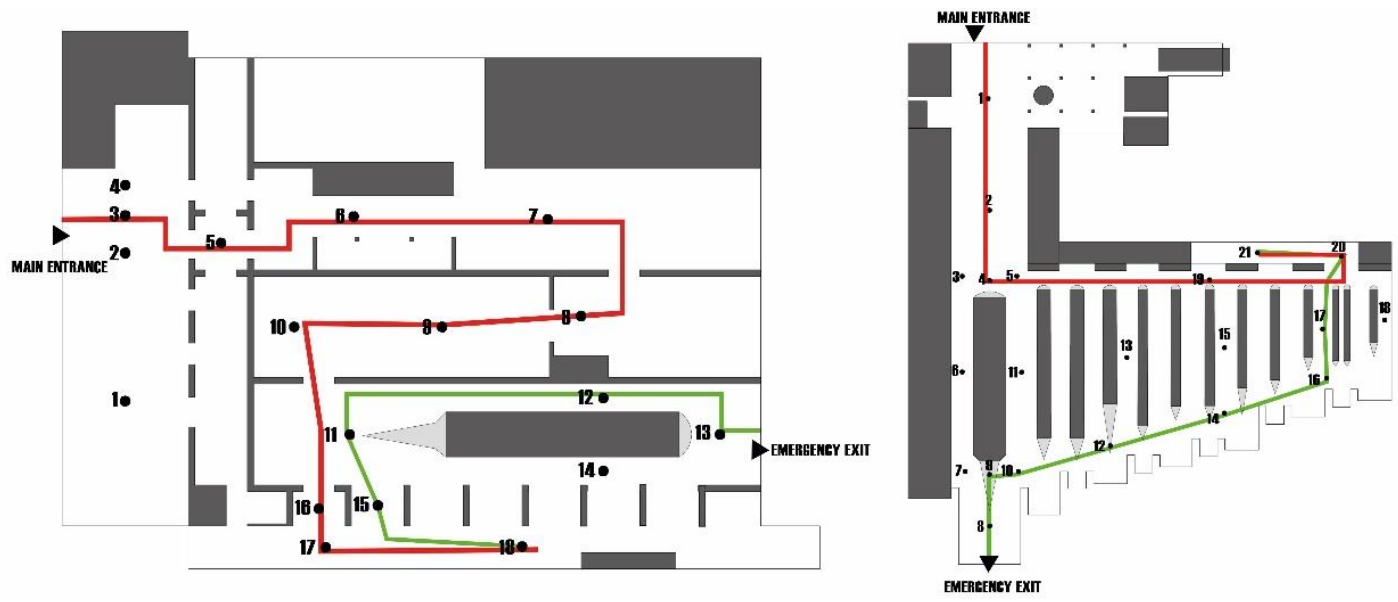

Figure 10 Genova Galata Museo Del Mare's Character of the Routes (left) İstanbul Deniz Müzesi Character of the Routes (right)

Respecting the purpose of the study, the convex spaces were defined in order to show the relationship between the spaces. The main entrances, entrance to the exhibition areas, the movement zones and emergency exits, which are proposed secondary entrances were described as convex spaces at both museums. The routes starting from the main entrances and combining the convex spaces are shown in Figure 9 and routes in Figure 10. The relationship between main entrance-emergency exit and exhibition fields in each museum is achieved by the isovist analysis (Table 2 -3).

In Figure 11, In Galata Museo del Mare, it is seen that the general layout of the museum had moderate circularity value which is homogenous. While the entrance hall's connectivity value is high, the general layout has an average value, and the emergency exit has a low connectivity value. The integration value has a similar tendency to the connectivity value. In addition to that, while the mean depth value is low at the emergency exit, in general, it is an average value. 
Similarly, In Figure 11, in the İstanbul Deniz Müzesi, the entrance hall and the overall of the museum have average circularity value, but between the galleys which are indicated as walls, the value of circularity is low. The connectivity and integration values are compatible with each other. At the entrance and entrance to the main exhibition hall values are high, but between the galleys has low integration and circularity values. Unlike the Galata Museo del Mare, the mean depth value has similarities at the main entrance and emergency exit in ístanbul Deniz Müzesi. The mean depth throughout the museum is average, but it is low among the galleys. In Table 1, the numerical values of circulation, connectivity, integration, and mean depth analyses have been given according to the coordinates of nodes indicated in Figure 9.

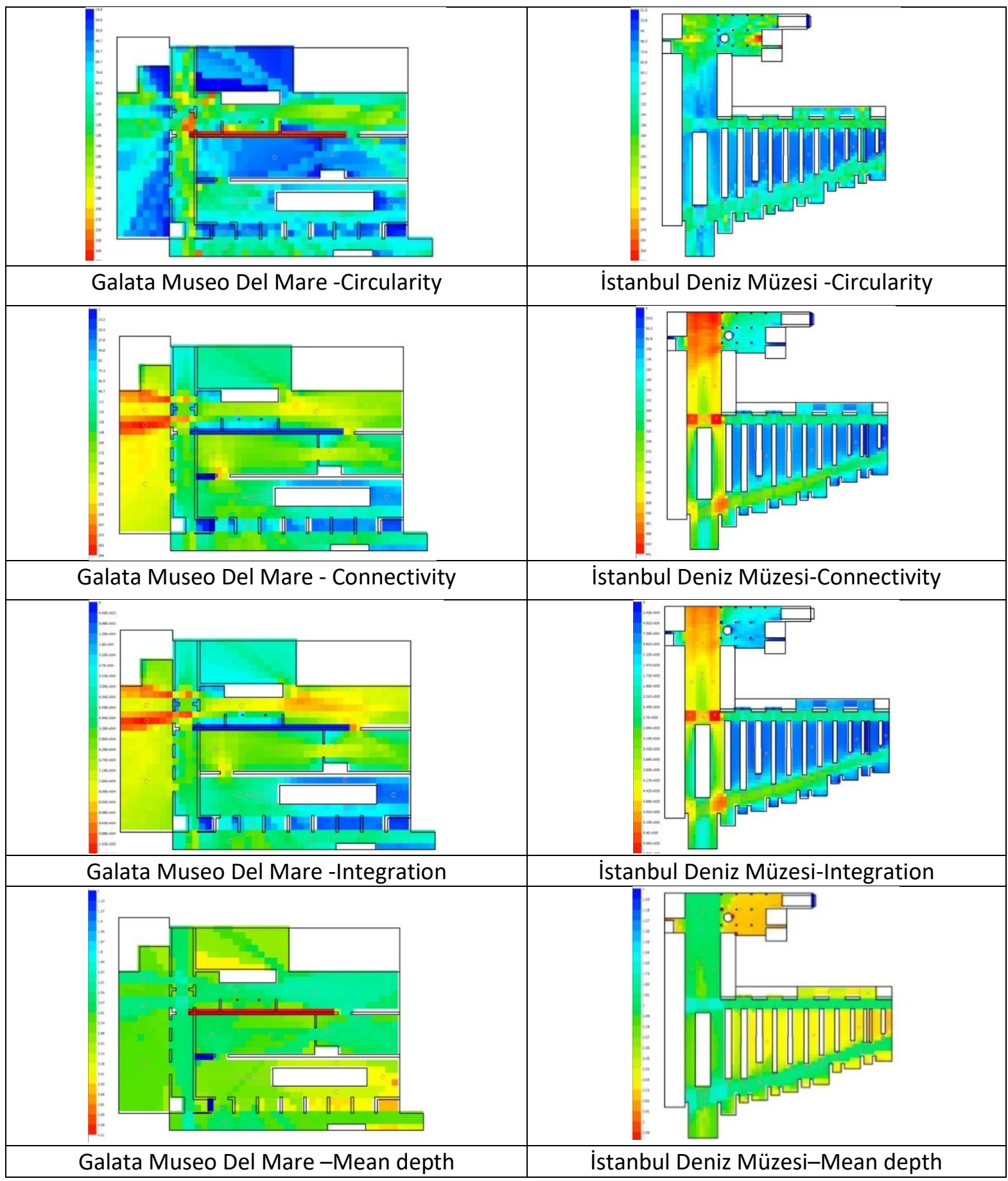

Figure 11 The circularity, connectivity, integration, and mean depth map 
Table 1 The syntactic value of each node- Genova Galata Museo Del Mare(up), İstanbul Deniz Müzesi(down) (Nodes isovist fields are indicated in Table 2-3).

\begin{tabular}{|c|c|c|c|c|}
\hline \multicolumn{6}{|c|}{ Galata Museo Del Mare } \\
\hline NODE & Circularity & Connectivity & Mean Depth & Integration \\
\hline $\mathbf{1}$ & $\mathbf{4 8}$ & $\mathbf{2 1 8}$ & $\mathbf{2 . 6 8 8}$ & $\mathbf{7 5 2 6 7}$ \\
\hline 2 & 122 & 286 & 2.373 & 104486 \\
\hline $\mathbf{3}$ & $\mathbf{7 9}$ & $\mathbf{2 2 6}$ & $\mathbf{2 . 6 4 0}$ & $\mathbf{7 8 3 3 9}$ \\
\hline 4 & 152 & 259 & 2.371 & 933538 \\
\hline $\mathbf{5}$ & $\mathbf{2 4 0}$ & $\mathbf{2 0 4}$ & $\mathbf{2 . 2 0 1}$ & $\mathbf{7 7 9 3 9}$ \\
\hline $\mathbf{6}$ & $\mathbf{9 6}$ & $\mathbf{1 8 7}$ & $\mathbf{2 . 4 3 3}$ & $\mathbf{7 9 0 4 0}$ \\
\hline 7 & 168 & 212 & 2.195 & 88152 \\
\hline 8 & 57 & 203 & 2.329 & 76732 \\
\hline 9 & 45 & 164 & 2.612 & 59888 \\
\hline 10 & 75 & 192 & 2.456 & 68057 \\
\hline 11 & 998 & 143 & 2.856 & 45788 \\
\hline $\mathbf{1 2}$ & $\mathbf{7 5}$ & $\mathbf{4 6}$ & $\mathbf{3 . 1 9 1}$ & $\mathbf{1 3 1 5 9}$ \\
\hline $\mathbf{1 3}$ & $\mathbf{4 7}$ & $\mathbf{4 5}$ & $\mathbf{3 . 4 0 9}$ & $\mathbf{1 1 4 2 4}$ \\
\hline $\mathbf{1 4}$ & $\mathbf{8 2}$ & $\mathbf{8 4}$ & $\mathbf{3 . 2 3 6}$ & $\mathbf{2 2 9 1 2}$ \\
\hline 15 & 54 & 100 & 2.902 & 33033 \\
\hline 16 & 57 & 78 & 2.594 & 26691 \\
\hline 17 & 107 & 150 & 2.485 & 51650 \\
\hline 18 & 116 & 129 & 2.694 & 42782 \\
\hline
\end{tabular}

\begin{tabular}{|c|c|c|c|c|}
\hline İstanbul Deniz Müzesi \\
\hline NODE & Circularity & Connectivity & Mean Depth & Integration \\
\hline $\mathbf{1}$ & $\mathbf{1 8 9}$ & $\mathbf{5 6 7}$ & $\mathbf{1 . 9 8 9}$ & $\mathbf{4 7 1 4 4}$ \\
\hline 2 & 98 & 437 & 2.090 & 392400 \\
\hline $\mathbf{3}$ & $\mathbf{1 3 1}$ & $\mathbf{6 0 2}$ & $\mathbf{1 . 6 7 3}$ & $\mathbf{5 4 7 9 9 9}$ \\
\hline 4 & 94 & 509 & 1.757 & 468438 \\
\hline $\mathbf{5}$ & $\mathbf{1 1 8}$ & $\mathbf{6 3 6}$ & $\mathbf{1 . 6 5 5}$ & $\mathbf{5 8 5 8 5 6}$ \\
\hline $\mathbf{6}$ & $\mathbf{8 2}$ & $\mathbf{2 7 1}$ & $\mathbf{2 . 1 8 6}$ & $\mathbf{2 4 2 0 6 6}$ \\
\hline $\mathbf{7}$ & $\mathbf{1 4 8}$ & $\mathbf{4 7 2}$ & $\mathbf{1 . 7 5 0}$ & $\mathbf{4 3 0 5 3 9}$ \\
\hline 8 & 66 & 188 & 2.386 & 169265 \\
\hline 9 & 87 & 317 & 1.971 & 296350 \\
\hline $\mathbf{1 0}$ & $\mathbf{1 3 8}$ & $\mathbf{5 4 2}$ & $\mathbf{1 . 7 1 1}$ & $\mathbf{4 9 7 9 6 7}$ \\
\hline $\mathbf{1 1}$ & $\mathbf{7 2}$ & $\mathbf{3 9 4}$ & $\mathbf{2 . 0 8 5}$ & $\mathbf{3 5 7 7 5 8}$ \\
\hline 12 & 131 & 357 & 1.924 & 319764 \\
\hline 13 & 57 & 96 & 2.644 & 68435 \\
\hline 14 & 114 & 351 & 1.921 & 310426 \\
\hline 15 & 53 & 98 & 2.633 & 68497 \\
\hline 16 & 124 & 291 & 1.957 & 250703 \\
\hline 17 & 56 & 76 & 2.689 & 52137 \\
\hline 18 & 39 & 51 & 2.765 & 35265 \\
\hline 19 & 130 & 217 & 2.010 & 201356 \\
\hline 20 & 162 & 138 & 2.569 & 88561 \\
\hline 21 & 101 & 157 & 2.537 & 104254 \\
\hline
\end{tabular}

The routes of the museums are shown in Figure 10. The visibility of the route is indicated node of specific intervals depending on the spatial configuration. The visual perception of spaces and their spatial relations are represented with isovist maps which are shown in Table 2 and Table 3.

The entrance of Galata Museo del Mare and isovist values of the route are demonstrated in Table 2. As stated in the table, 1,3,5 and 6 nodes generate the visual perception from the main entrance. The 12,13,14 nodes demonstrate the isovists between the emergency exit and exhibition venue. It is understood that both the main entrance and emergency exit have a visual relationship with exhibition fields.

Table 2 represents the isovist values of the route and the entrance of İstanbul Deniz Müzesi. According to nodes $1,3,5,6,7,10$ and 11 isovists, both the main entrance and emergency exit perceive each other visually. It is determined that the main goal of the study is the landside and seaside entrances to provide both accessibility and visibility. Moreover, nodes 3 and 5 have high integration values. Therefore, the isovist maps support the route and organization of convex space. Both doors are visually related to the museum's exhibition hall (Figure 12 and 13).
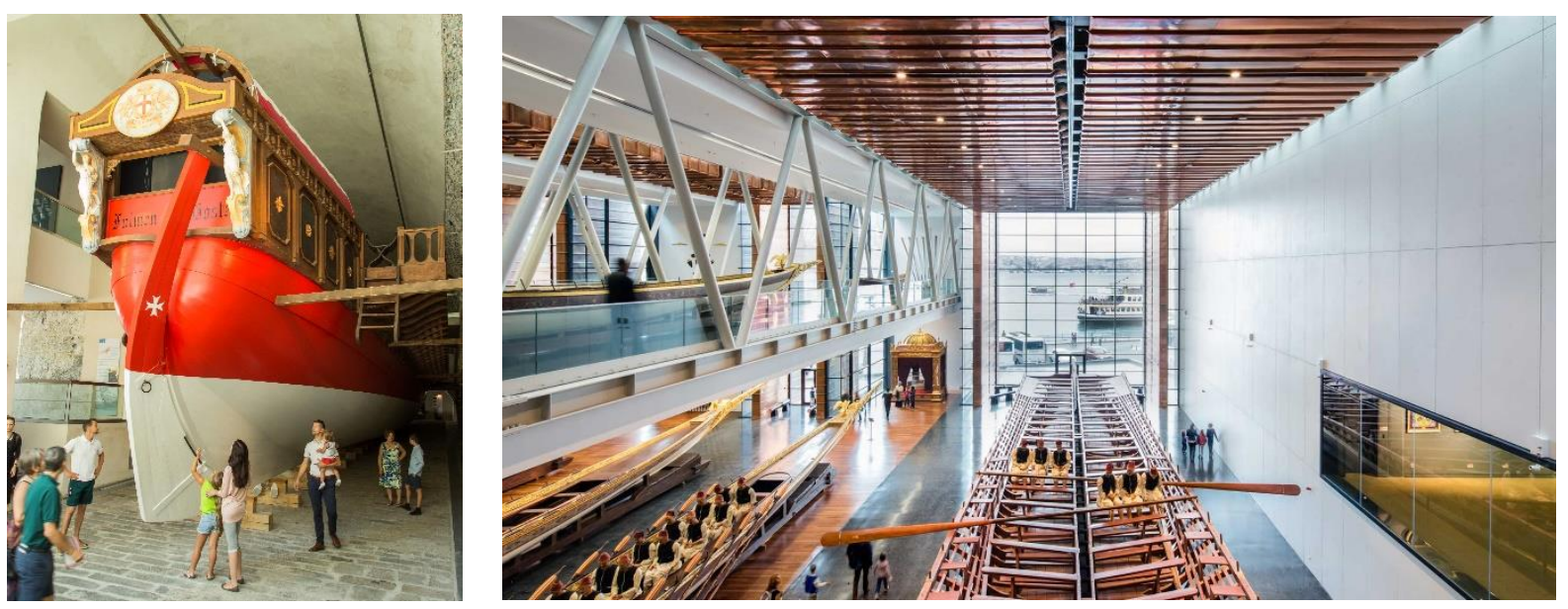

Figure 12 (left) Genova Galata Museo Del Mare's view from the emergency exit (URL-4), Figure 13 (right) İstanbul Deniz Müzesi's view from main entrance hall to emergency exit (URL-3) 
Table 2 Isovist graphs of each node- Genova Galata Museo Del Mare (Nodes from Figure 10)

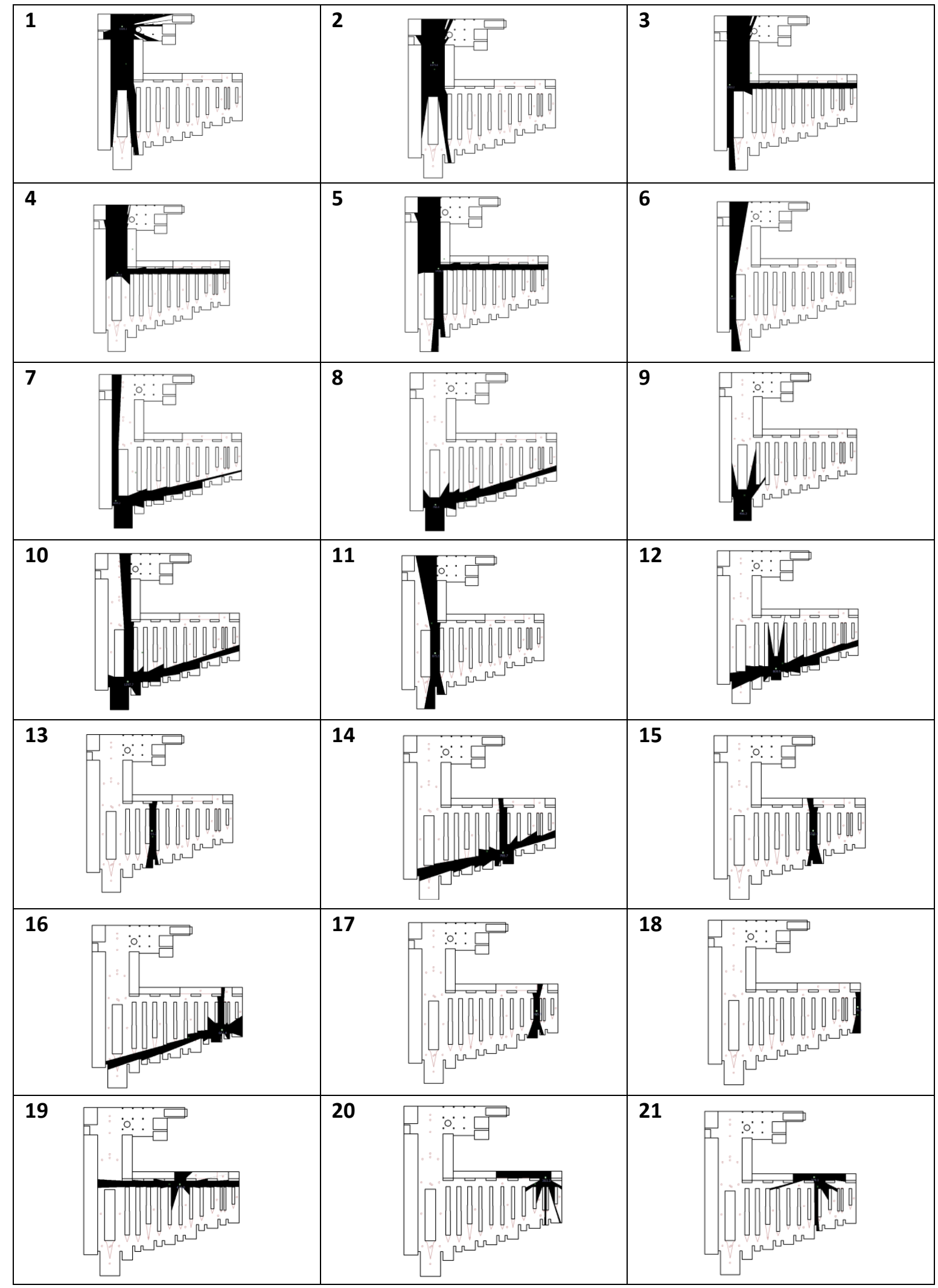


Table 3 Isovist graphs of each node- İstanbul Deniz Müzesi (Nodes from Figure 10)

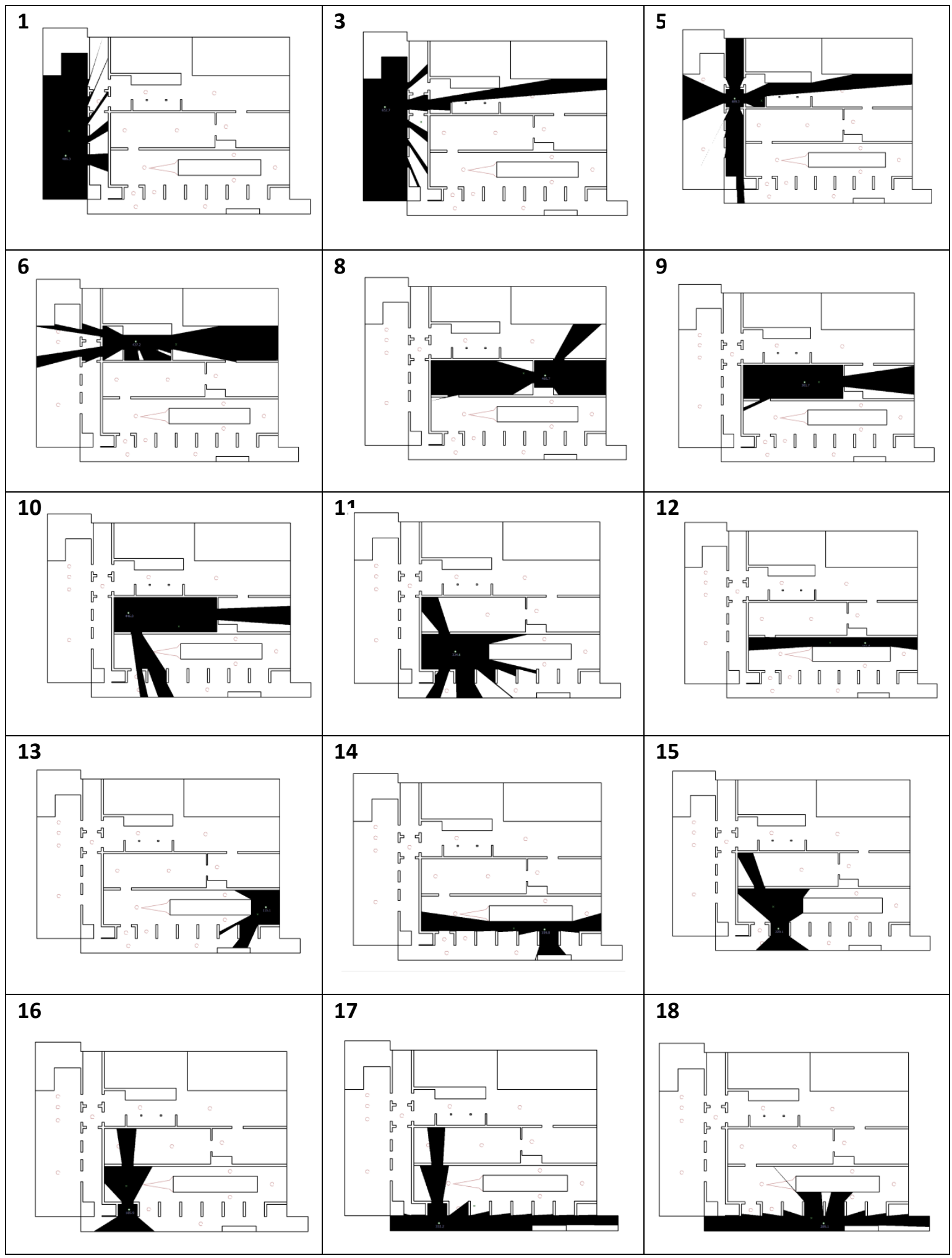

Page | 378 


\section{Conclusion}

The study examines the two different naval museums between the sea and the land. In the Genova case, the seaside entrance is actively used, but the land side is used as an emergency exit. On the contrary, in the İstanbul case, the situation is the opposite. Although they are visible from both sides, İstanbul Deniz Müzesi is accessible from the landside and the Galata Museo del Mare is accessible from the seaside. Thus, the relationship between both sides and exhibition venues is evaluated in Table 4 by applying the Space Syntax 2D tool.

Table 4 Evaluation of space syntax measurements

\begin{tabular}{|l|l|l|l|l|}
\hline \multirow{2}{*}{} & \multicolumn{2}{|l|}{ Galata Museo Del Mare } & İstanbul Deniz Müzesi \\
\cline { 2 - 5 } & Main Entrance & Emergency Exit & Main Entrance & Emergency Exit \\
\hline Circularity & Average & Low & Average & Low \\
\hline Connectivity & High & Low & High & Average \\
\hline Integration & High & Low & High & Average \\
\hline Mean depth & Low & Average & Low & Average \\
\hline
\end{tabular}

According to the data obtained, while the main entrance of the Galata Museo del Mare on the seaside is average in terms of circularity and mean depth, it is highly dense in connectivity and integration value. In the analyses made for the emergency exit door on the land side of Galata, circularity, connectivity and integration value are found in low intensity and medium depth. In the Istanbul museum; the main entrance circularity value on the land side is average, the connectivity and integration value is seen as intense. Moreover, the emergency exit door on the seaside has a low circularity value and the connectivity, integration and means depth value is average (Table 4).

While the İstanbul Deniz Müzesi faces to square that the active vehicle and pedestrian traffic on the mainland side, the emergency exits face to the public square that ferry port and pedestrian flow on the seaside. The museum is located that separates these two public open spaces. The main purpose of this study is to make a connection between two axes by applying the circulation, connection, integration analysis to the interior space of the museum. According to analysis, if active usage and permission will be provided between the main entrance and emergency exit in the interior space, the museum will become a more permeable urban transition bridge.

Unlike İstanbul Deniz Müzesi, Galata Museo Del Mare's main entrance faces the square at the seaside, while the emergency exit opens to public areas and pedestrian flow on the mainland side.

The circulation, connection, integration analysis demonstrates that similarly Istanbul Deniz Müzesi if the active usage and the transition are provided between the main entrance and emergency exit, the museum's interior space will gain permeability features.

The naval museums are urban bridges that provide fluidity among the land and sea, make connections. It is necessary not only to be visible from sea and land but also to be accessible from both sides. Using the emergency exit as a secondary entrance to provide social space and urban relations on the land side of the Galata museum will increase the land-sea relationship, circulation, connection, integration, and visibility.

With the same approach, the use of the emergency exit overlooking the sea transportation piers and urban open areas of the Istanbul Deniz Müzesi will increase the land-sea relationship, circulation, connection, integration, and visibility. For this purpose, having similar location features, Istanbul Deniz Müzesi where is at the Marmara Sea and Galata Museo del Mare where is at the Mediterranean Sea, the sea-land relationship will support accessibility and visibility in future use. 


\section{References}

Benedikt, M. L. (1979). To Take Hold of Space: Isovist and Isovist fields. Environment and Planning B volume 6:47-65.

Benedikt, M. L. (1993). Cityspace, Cyberspace, and The Spatiology of Information New Urbanism Symposium, Princeton University, School of Architecture and Planning, Princeton, New Jersey; October 17, 1992

Beydiz, M. (2018). Italya Deniz Müzeciliği Trieste Civico Museo Del Mare ve Genova Museo Del Mare Örnekleri, Hars Akademi Uluslararası Hakemli Kültür Sanat Mimarlık Dergisi, 1 (2), 54-81. Retrieved May 9, 2020, from https://dergipark.org.tr/tr/pub/hars/issue/39949/483791

Dalton, C., D., R. and Dalton, N. (2001)., OmniVista: an application for isovist field and path analysis, In: 3rd International Space Syntax Symposium, 7-11 May 2001, Atlanta, Georgia, USA.

Gülhan, D. (2014). İstanbul Deniz Müzesi. Arkitera. Retrieved May 9, 2020, from https://www.arkitera.com/proje/istanbul-deniz-muzesi/

Hillier, B., Burdett, R., Peponis, J., Penn, A. (1987) Creating life, or does architecture determine anything? Architecture and behavior/Architecture et comportment, 3, 233-250.

Hillier, B., and Hanson J. (1984). The Social Logic of Space, Cambridge University Press, Cambridge

Hillier, B. (2005). The art of place and the science of space, World Architecture 11/2005 185, Beijing, Special Issue on Space Syntax pp 24-34 in Chinese, pp 96-102 in English

Hillier, B., et al. (1993). Natural Movement, Environment and Planning B, Volume 207

Hillier, B., \& Tzortzi, K. (2006). Space syntax: the language of museum space. A companion to museum studies, 282-301.

Klarvist, B. (1993). A Space Syntax Glassory, Nordisk Arkitekturfoskning 2:11-12

Kuipers, B., Tecuci, D., \& Stankiewicz, B. (2003). The skeleton in the cognitive map: A computational and empirical exploration. Environment and Behavior, 35, 81-106.

Lefebvre, H. (1991). The Production of Space, T. Donald Nicholson-Smith, Blackwell, Oxford.

Peponis J., and Wineman J.D. (2010). Construction Spatial Meaning: Spatial Affordances in Museum Design, Environment and Behavior, 42; 86-109

Şalgamcıoğlu, M. E. (2013). Istanbul'da Çoklu Konut Gelişiminin Semantik ve Sentaktik Olarak irdelenmesi: 1930-1980 Dönemi (Doctoral dissertation, ITU Fen Bilimleri Enstitüsü)

Şalgamcıoğlu, M., E., Cimşit Koş, F., Garip, E. (2015). Tracing a biennial layout: Experiencing an exhibition layout through the syntactic analysis of Antrepo No. 3 at the 2013 Istanbul Biennial, ITU A/Z, Volume 12, No 3

Ünlü, A. and Edgü, E., (2007). Comparative Space Syntax Analysis of Design Strategies for Istanbul Underground Railway System, Proceedings, 6th International Space Syntax Symposium, İstanbul

Van de Ven A. H., (1974). Group Decision Making Effectiveness: An Experimental Study, Kent, Ohio: Kent State University, CBER Press, College of Business Administration

URL-1 Retrieved May 9, 2020, from, http://mimdap.org/2012/05/galatanyn-bir-muzesi/89046/\#yukari

URL-2 Retrieved April 25, 2020, from, https://earth.google.com/web/

URL-3 Retrieved April 25, 2020, from, https://www.teget.com/works/istanbul-maritime-museum/

URL-4 Retrieved June 01, 2020, from, https://www.giovanigenitori.it/dove-andare/galata-museo-del-maregenova/

\section{Resume}

\section{Nurcan Gül}

Born in 1983, Elazığ. She was graduated from Kayseri Erciyes University, Faculty of Architecture in 2006. In January 2015, she completed her master's degree at Yıldız Technical University with the thesis 'Prison Architecture in Turkey and around the World and Discussion of Current Design Criteria'. She published 'An Investigation of the Contemporary Wooden Construction Systems Usage in Multi-Storey Buildings: The Tree' in September 2019. She has registered to Gebze Technical University-Graduate School of Science and 
Engineering and Technology since 2018.

2006- 2015: Istanbul City Administrations, Zoning Investment and Construction Department, Investment and Construction Directorate,

2015- 2017: Istanbul Governorship Investment Monitoring and Coordination Department, Natural Resources, License and Cultural Heritage Directorate

Page| 381 2017- : Istanbul Metropolitan Municipality Rail Systems Department, Anatolian Side Rail System Directorate, 2021-. : Karabük University, Faculty of Architecture, Guest Lecturer

\section{Sevilay Erk}

Born in 1992, Bursa. She was graduated from Middle East Technical University in 2016 with honor. In December 2018, she completed her master's degree at Politecnico di Milano with the thesis 'Re-writing Aleppo-The Reconstruction of the Old City Centre' with honor. She has registered to ITU-Graduate School of Science and Engineering and Technology since 2020 February.

2021- : Istanbul Okan University, Faculty of Art, Design and Architecture, Lecturer 